\title{
An Analysis of Factors Affecting Decisions on Investment in HCMC Municipal Bonds
}

\author{
Nguyễn Thị Mỹ Linh \\ Industrial University of Hochiminh City \\ mylinhdhen@yahoo.com.vn \\ Phùng Thị Cẩm Tú \\ Industrial University of Hochiminh City \\ phungcamtu@yahoo.com \\ Đào Thị Minh Huyền \\ University of Economics HCMC \\ minhhuyen@ueh.edu.vn
}

\author{
Dương Thị Bình Minh \\ University of Economics HCMC \\ dbminh@ueh.edu.vn \\ Vũ Thị Minh Hằng \\ University of Economics HCMC \\ vuhangngoc16@yahoo.com.vn \\ Diệp Gia Luật \\ University of Economics HCMC \\ gialuat@ueh.edu.vn
}

\section{ARTICLE INFO}

Article history:

Received:

May 30, 2013

Received in revised form Sep. 24, 2013

Accepted:

Dec. 31,2013

Keywords:

bonds, municipal bonds, affecting factors, investment decisions.

\section{ABSTRACT}

The paper analyzes factors affecting decisions on investment in HCMC municipal bonds for infrastructure projects. Results of EFA and regression analysis show that decisions on investment in HCMC municipal bonds depend on five factors with adjusted R2 equaling 72,1\%: (1) government's policies; (2) bonds and issuers; (3) infrastructure projects and socioeconomic conditions; (4) economicfactors; and (5) impacts of relevant markets.

This serves as a basis for policy recommendations that aim at enhancing the mobilizing power of municipal bonds for infrastructure project in particular and socioeconomic development in HCMC in general. 


\section{INTRODUCTION}

Investments in infrastructure projects play a crucial role in the local socioeconomic development in particular and generate motivation for socioeconomic development in general. The issue is that demand for capital is huge, calling for the mobilization of various sources, among which issuing municipal bonds is one of the effective methods, offering low-interest and long-term capital for infrastructure and other social welfare projects.

However, although HCMC has been the first city to issue municipal bonds, this source of capital reveals several limitations; for instance, municipal bond markets in HCMC and other provinces or cities have not developed; issuers did not care about trade in such bonds on the stock market; capital from the bonds is very small in comparison with the demand for capital for infrastructure construction; and this commodity does not attract the attention of investors.

To enhance the mobilizing power, therefore, the paper analyzes the factors affecting decisions on investment in HCMC municipal bonds and provides policy recommendations for effective mobilization of municipal bond capital for infrastructure projects and socioeconomic development in HCMC.

\section{RESEARCH DATA AND METHODOLOGY}

\section{a. Data:}

The data was collected by distributing ready-designed questionnaires directly or electronically to the respondents being managers, officials, and employees from investment funds, banks, securities firms, etc. in HCMC [1]. The survey ran from September to October 2012, coming up with a sample of 180 returned questionnaires $[2]$.

\section{b. Methodology:}

Various methods combined and employed in the study include survey, analysis, synthesis, among which the principal one is factor analysis with a regression model and the support of SPSS to assess the impact of the factors affecting decisions on municipal bond investment.

3. THEORY OF MUNICIPAL BONDS AND FACTORS AFFECTING DECISIONS ON THE BOND INVESTMENT

\section{a. Theory of Municipal Bonds:}


Bond is a kind of debt instrument on financial market, confirming the obligation of the issuers to pay both principal and interest on a specified date. There are many different classes of bonds on financial markets, including government bond, municipal bond and corporate bond.

In Japan's perspective, municipal bonds are issued by local government to cover part of the cost, forming the debts tackled by the government and being purchased by private financial institutions often with a maturity of over a year. [3]

In Vietnam, a municipal bond, aka "local bond," is a type of bond issued by provincial/municipal people's committee according to annual plans of local budget or finance income-generating works. [4]

In legal terms, municipal bonds are issued by provincial/municipal people's committee directly under central authority to raise fund for local investment projects. [5]

The two basic types of municipal bond on financial markets are general obligation bond and revenue bond. The issuers are people's committees of provinces and cities directly responsible to the central government. They may have bonds issued by local branches of National Treasury or other financial/ credit institutions to raise funds for locally-financed works.

Methods of municipal bond issuance consist of bidding through the SBV and Stock Exchange, underwriting, issuance through issuing agency or direct issuance through National Treasury.

Regarding issuance mechanism, the basic criteria to be adhered to include the following: legal basis of municipal bond issuance, types of issued bond, volume of capital mobilized by bonds, principles and methods of issuance, credit rating, interest rate, bond repayment when due, management of mobilized capital and purposes of capital usage

\section{b. Factors Affecting Decisions on Municipal Bond Investment:}

Today, in the trend of international and regional economic integration, Vietnam has gradually engaged in global business and investment. Accordingly, investment in municipal bonds also follow market mechanisms and competitive bidding [6]; theoretical basis and results of qualitative research show that decisions on such investment are governed by the following factors: 
- Legal and institutional factors: They include the stability of laws, relevant tax policies and laws such as Investment Law, Companies Law, Labor Code, and Antitrust Law, and other relevant policies. These factors have influenced all economic sectors in a territory concerning their survival and growth.

- Economic factors: These factors have considerable effects on the economy, such as interest rates, inflation, state of the economy, economic policies and future prospects like growth rates, GDP growth, ratio of GDP to investment, etc. Enterprises should pay attention to the economic factors in the short and long run and government intervention, which usually serve as a basis for their investment decisions.

- Socio-cultural factors: Each country or region has its cultural values and specific social factors, which feature characteristics of the consumers in that area. Besides cultural traits, social aspects also attract attention among enterprises in market research and business investment decisions.

- Technological factors: These voice concerns among business units when investment decisions are made. Such concerns include public investment, technology replacement, and impact of IT or Internet on business operations.

- Integration: In addition to these basic elements, current studies on the market also notice the importance of globalization, a macroeconomic factor affecting all sectors.

\section{RESEARCH MODEL}

To analyze and identify the factors that influence decisions to invest in HCM municipal bonds, authors conducted a survey to gather firsthand data and developed a 5level questionnaire (Likert scale). The initial model includes seven groups of factors affecting the decisions. After a preliminary study to adjust the scale, the main research and necessary tests were conducted. The research came up with only five groups of factors affecting the decisions on HCM municipal bond investment: (1) laws and policies, (2) bonds and issuers, (3) infrastructure development projects and socioeconomic factors, (4) economic factors, and (5) impact of relevant markets.

Descriptive statistics illustrates that in the laws and policies group, the factors "transparent management of infrastructure projects and capital from issued bonds" and "legal framework for municipal bond market" are considered the most influential in the decisions (3.21). In the bonds and issuers group, the factor "market price of bonds" seems to have the greatest impact (2.92) along with other factors. 


\section{Table 1: Impact of Factors Affecting Decisions on HCM Municipal Bond Investment}

(1: no impact; 2: slight impact; 3: medium impact; 4: large impact; 5: very large impact)

\begin{tabular}{|c|c|c|c|c|}
\hline \multicolumn{3}{|c|}{ Group of factors } & Level of impact & \multirow{2}{*}{$\begin{array}{c}\begin{array}{c}\text { Average } \\
\text { score }\end{array} \\
3.21\end{array}$} \\
\hline \multirow{3}{*}{ A } & \multirow{3}{*}{ Laws and policies } & a1 & Legal framework for municipal bond market & \\
\hline & & a2 & Incentive to investment and development of local & 3.11 \\
\hline & & a3 & Transparent management of infrastructure projects & 3.21 \\
\hline \multirow{5}{*}{ B } & \multirow{5}{*}{ Bonds and issuers } & b1 & Market price of bonds & 2.92 \\
\hline & & $\mathrm{b} 2$ & Procedure for interest payment & 2.81 \\
\hline & & b3 & Bond-issuing procedure & 2.42 \\
\hline & & b4 & Risk-preventing measures for bond issuance & 2.84 \\
\hline & & b5 & Bond creditworthiness & 2.90 \\
\hline \multirow{6}{*}{$\mathrm{C}$} & \multirow{6}{*}{$\begin{array}{l}\text { Infrastructure } \\
\text { development } \\
\text { projects and } \\
\text { socioeconomic } \\
\text { factors }\end{array}$} & $\mathrm{c} 1$ & Project managing competence & 3.31 \\
\hline & & $\mathrm{c} 2$ & Socioeconomic effects of the projects & 3.38 \\
\hline & & $\mathrm{c} 3$ & Local population growth & 3.02 \\
\hline & & $\mathrm{c} 4$ & Improvement in welfare and living standard by the & 3.11 \\
\hline & & $\mathrm{c5}$ & Possibility of promoting businesses & 3.26 \\
\hline & & c6 & Enhancement in terms of quantity and quality of & 3.06 \\
\hline \multirow{3}{*}{$\mathrm{D}$} & \multirow{3}{*}{ Economic factors } & d1 & Inflation rate & 3.83 \\
\hline & & $\mathrm{d} 2$ & Market interest rate & 3.37 \\
\hline & & $\mathrm{d} 3$ & Impact of capital flows in the economy & 3.34 \\
\hline \multirow{3}{*}{$\mathrm{E}$} & \multirow{3}{*}{$\begin{array}{l}\text { Impact of relevant } \\
\text { markets }\end{array}$} & e1 & Development of financial market in Vietnam & 3.56 \\
\hline & & $\mathrm{e} 2$ & Impact of stock market & 3.49 \\
\hline & & e3 & Impact of bond market & 3.51 \\
\hline
\end{tabular}

Source: Authors' survey and calculations 


\section{ANALYZING AND TESTING THE MODEL}

\section{a. Analysis of Factors Affecting Decisions on HCM Municipal Bond Investment:}

- Group A - Laws and policies

System of laws and policies relating to municipal bonds regulate bond issuance, issuers, classes of bonds, circulation of bonds, tax obligations, and rights and obligations of the parties involved in bond transactions.

The legal system, accordingly, is a key factor directly affecting investment decisions. However, in the past the system of laws and policies has not created favorable conditions for the development of municipal bonds. In early 1994 HCMC People's Committee asked the Ministry of Finance to approve a pilot scheme to issue bonds to fund Nguyễn Tất Thành Street Project for the first time. Total required investment for the project was VND41.8 billion, 30 billion of which was from municipal bonds.

After Decree 93/2001/NĐ-CP dated Dec. 12, 2001 on delegation of managerial authority in certain fields to HCMC government was issued, the city was allowed to raise funds by issuing municipal bonds, and the plan was later established. However, it was not until the promulgation of Decree 141/2003/NĐ-CP dated Nov. 20, 2003 and modified, adjusted and substituted by Decree 01/2011/NĐ-CP dated Jan. 5, 2011 that the issuance was really launched.

Following the plan, HCMC raised VND2,000 billion per year by means of bond issuance in the period 2003 - 2007, mostly from financial institutions and commercial banks. The year 2009 first recorded municipal bonds for income-generating public works, particularly for the project of Thủ Thiêm New Urban Area with a plan to issue VND4,000 billion worth of bonds, and in fact, underwriters raised VND1,540 billion. The system of laws on bond issuance that was enacted, adjusted, modified, and improved is a necessary condition and a legal corridor for effective and legal issuance that creates faith for investors.

- Group B - Municipal bonds and issuers:

Municipal bond is a kind of debt instrument in financial markets, confirming the obligation of the issuers to pay both principal and interest on a specified date. The two basic types of municipal bond are general obligation bond and revenue bond, the interest rate of which is decided by issuers for each series of issuance. The period $2003-2007$ marked the issuance of the former, which was also issued in 2009 for income-generating works included in the Thủ Thiêm New Urban Area Project. 
The issuer was HCM People's Committee, authorizing the Investment Fund for Urban Development to issue the bonds. Sources of capital used for principal and interest payments of general obligation bond come from the city's budget. Due to the characteristics and financial resources to ensure its solvency, HCM municipal bonds, compared to other types of bonds in the market, gain a high creditworthiness. However, bond purchasers, besides interest rate and market price, are particularly interested in issuers and their ability to maintain budget balance and repay bond principal and interest.

Table 2: Issuance of HCM Municipal Bonds (VND billion)

\begin{tabular}{|c|c|c|c|c|c|c|c|c|c|c|c|}
\hline \multirow{2}{*}{ Year } & \multicolumn{2}{|c|}{ 2-year term } & \multicolumn{2}{|c|}{ 3-year term } & \multicolumn{2}{|c|}{5 -year term } & \multicolumn{2}{|c|}{10 -year term } & \multicolumn{2}{|c|}{15 -year term } & \multirow{2}{*}{$\begin{array}{l}\text { Total } \\
\text { value }\end{array}$} \\
\hline & Value & Interest rate & Value & Interest rate & Value & Interest rate & Value & Interest rate & Value & Interest rate & \\
\hline 2003 & 200 & $8.52 \%$ & & & 1,800 & $9 \%$ & & & & & 2,000 \\
\hline 2004 & & & & & 1,600 & $\begin{array}{l}8.5 \% \\
-8.7 \%\end{array}$ & 400 & $9 \%$ & & & 2,000 \\
\hline 2005 & & & & & 1,035 & $\begin{array}{c}9 \% \\
-9.05 \%\end{array}$ & & & 965 & $9.55 \%$ & 2,000 \\
\hline 2006 & & & & & 850 & $\begin{array}{c}8.8 \% \\
-9.05 \%\end{array}$ & 525 & $\begin{array}{l}9.15 \% \\
-9.25 \%\end{array}$ & 625 & $\begin{array}{l}9.25 \% \\
-9.55 \%\end{array}$ & 2,000 \\
\hline 2007 & & & & & 756 & $8.50 \%$ & 742 & & 502 & & 2,000 \\
\hline 2008 & & & & & & & & & & & \\
\hline 2009 & & & 1,540 & $10 \%$ & & & & & & & 1,540 \\
\hline Total & 200 & & 1,540 & & 6,041 & & 1,667 & & 2,092 & & 11,540 \\
\hline
\end{tabular}

Source: HCMC Department of Finance

- Group C - Infrastructure development project and socioeconomic factors

Investing in municipal bonds, investors not only gain some interest payments but also support development of infrastructure, which leads to improvements in welfare and living standards and further development of local economy. Over the past ten years, funds raised from municipal bonds were invested in: (1) Projects belonging to HCMC key programs, (2) Projects to improve the HCMC local grid, (3) Construction of industrial parks/clusters in HCMC, (4) Project on compensation, site clearance, construction of residential resettlement quarters, and (5) Other projects with loans approved by HCMC People's Committee on a case-by-case basis.

Municipal bond investors also examine project management to ensure it would be right on schedule and of high quality, and they want the projects to be socioeconomically 
efficient. Particularly infrastructure to be built should match urban, educational, and healthcare facilities, etc., to improve the quality of public services.

- Group D - Economic factors

Economic development and ability to attract capital flows will affect competitiveness as well as decisions on the investment portfolio made by investors. In contrast, inflation or increases in market interest rates will be a serious obstacle to the bond issuers. In other words, bond investors will demand a higher rate of return or higher bond interest rates.

In the period 2006 - 2007 or 2009 for example, when financial market was heating up and investment in stocks brought attractive profits as well as high liquidity, investors showed less interest in bonds. Effects of economic crisis and recession, and high inflation rates without flexible and prompt adjustment to interest rates produced very bad impacts on the HCMC bond issuance in 2009.

- Group E - Impact of Relevant Markets

Liquidity of the bonds depends primarily on the development of financial markets, which, once developed, will create more commodities deemed competitive against municipal bonds. Thus, investors always show concerns with the liquidity and profitability of bonds versus those of other financial assets.

Over the courses of bond issuance in HCMC, the fact that stock market underwent volatility in 2003 also affected the bond market in 2004 and 2005. Since 2006 and 2007, the warming of the stock market has completely overwhelmed the bond market in general and municipal bond market in particular, which made investors stop caring about bonds with low and fixed profitability, while the reverse case rings true for investment in stocks. In 2003 bond purchasers came from all walks of life, and yet from 2004 onward those have been recorded mainly as commercial banks, insurance companies, and securities firms, etc., and issuance method would mainly be underwriting; investors made bond purchase, holding on to the bonds until their maturity.

\section{b. Model Testing:}

Multiple regression model is used to estimate the factors affecting decisions on HCMC municipal bond investment with the general form as follows:

$\mathrm{F}=\beta_{0}+\beta_{1} \mathrm{~A}+\beta_{2} \mathrm{~B}+\beta_{3} \mathrm{C}+\beta_{4} \mathrm{D}+\beta_{5} \mathrm{E}$

where:

Dependent variable F: Level of decisions on the bond investment 
Independent variables: A: Factor group of laws and policies, B: Factor group of municipal bonds and issuers, $\mathrm{C}$ : Factor group of infrastructure development projects and socioeconomic factors, D: Economic factors, and E: Impacts of relevant markets.

$\beta_{0}$ : level of impact of other factors apart from the main factors in the model

$\beta_{1}, \beta_{2}, \beta_{3}, \beta_{4}, \beta_{5}$, regression coefficients indicating the importance level of the factors affecting decisions on HCMC municipal bond investment

Hypotheses $\mathrm{H}_{0}: \beta_{1}=\beta_{2}=\beta_{3}=\beta_{4}=\beta_{5}=0$ (inappropriate model)

$\mathrm{H}_{1}$ : there exists at least a $\beta_{\mathrm{i}}$ different from $0[\mathrm{i}=1 \rightarrow 5]$ (appropriate model)

Testing the model:

- Determining the Cronbach's Alpha

Cronbach's Alpha is used to find significant variables for inclusion in factor analysis, and results are as follows:

Table 3: Determination of Cronbach's Alpha

\begin{tabular}{lcc}
\hline Factor & Cronbach's Alpha & Variables observed \\
\hline Group A & 0.623 & 3 \\
Group B & 0.933 & 5 \\
Group C & 0.924 & 6 \\
Group D & 0.635 & 3 \\
Group E & 0.956 & 3 \\
F (dependent variable) & 0.609 & 3 \\
\hline
\end{tabular}

Source: Authors' calculations

The results show that the variables in each factor group are correlated with one another since Cronbach's Alpha of each reaches a significance level greater than 0.6.

- EFA

Variables with satisfactory Cronbach's Alpha were included in EFA to assess convergence of the observed variables to select the significant factors for regression analysis. The KMO index is used to measure the sampling adequacy, a KMO value varying between 0.5 and 1 is a sufficient condition for a good factor analysis. 
Table 4: KMO and Bartlett's Test

\begin{tabular}{lll}
\hline KMO value & & 0.687 \\
\hline \multirow{2}{*}{ Bartlett's test } & Chi square estimation & $3,565.346$ \\
& Df & 190 \\
& Sig. & 0.000 \\
\hline
\end{tabular}

Source: Authors' calculations

Table 5: Rotated Component Matrix

\begin{tabular}{|c|c|c|c|c|c|}
\hline & \multicolumn{5}{|c|}{ Component } \\
\hline & 1 & 2 & 3 & 4 & 5 \\
\hline c5 & 0.907 & & & & \\
\hline $\mathrm{c} 1$ & 0.851 & & & & \\
\hline $\mathrm{c} 3$ & 0.839 & & & & \\
\hline c6 & 0.786 & & & & \\
\hline $\mathrm{c} 2$ & 0.768 & & & & \\
\hline $\mathrm{c} 4$ & 0.711 & & & & \\
\hline b2 & & 0.920 & & & \\
\hline b4 & & 0.901 & & & \\
\hline b5 & & 0.883 & & & \\
\hline b1 & & 0.866 & & & \\
\hline b3 & & 0.752 & & & \\
\hline $\mathrm{e} 1$ & & & 0.946 & & \\
\hline e3 & & & 0.936 & & \\
\hline $\mathrm{e} 2$ & & & 0.894 & & \\
\hline $\mathrm{a} 2$ & & & & 0.714 & \\
\hline a3 & & & & 0.709 & \\
\hline a1 & & & & 0.561 & \\
\hline $\mathrm{d} 3$ & & & & & 0.80 \\
\hline
\end{tabular}


d2

0.786

d1

0.651

Source: Authors' calculations

With a KMO value of 0.687 and Sig. 0.000, implying the model achieves a convergent value; all variables have factor loadings larger than 0.5. EFA comes up with 5 components being independent variables, which are included in the multiple regression model for the model testing.

\section{- Final test of the research model}

The test is undertaken with Enter method in which $\mathrm{F}$ (group F) is a dependent variable whereas A, B, C, D, and E (group A, B, C, D, and Erespectively) are independent variables. The results show that $\mathrm{R}^{2}$ is 0.721 , ANOVA ( $\mathrm{F}$ test) has Sig. <0.05; thus, independent variables are linearly correlated with dependent variables; the regression coefficient results are as follows:

Table 6: Summary of Regression Results

\begin{tabular}{cccc}
\hline Variable & $\begin{array}{c}\text { Unstandardized Coefficient } \\
(\mathbf{B})\end{array}$ & $\begin{array}{c}\text { Standardized Coefficient } \\
(\text { Beta })\end{array}$ & Sig. \\
\hline (constant) & $8.472 \mathrm{E}-17$ & & 1.000 \\
C & 0.131 & 0.131 & 0.001 \\
B & 0.336 & 0.336 & 0.000 \\
E & 0.156 & 0.156 & 0.000 \\
A & 0.744 & 0.744 & 0.000 \\
D & 0.144 & 0.144 & 0.000 \\
\hline
\end{tabular}

Note: D, A, E, B, C: independent variable \& F: dependent variable

The results show that all coefficients obtain Sig. $\leq 0.05$, proving that the independent variables included in the model have explanatory power; therefore, $\mathrm{H}_{1}$ is accepted and $\mathrm{H}_{0}$ is rejected. In addition, to assess the adequacy of the model, the coefficient $\mathrm{R}^{2}$ or adjusted $R^{2}$ is employed, indicating the fitness of the regression model based on the research data sets. 
The adjusted $\mathrm{R}^{2}=0.721$, implying $72.1 \%$ of the variation of investing entities would be explained by independent variables selected in the model. Therefore, it could be concluded that the model is suitable, and the regression function is:

$$
F=0,744 A+0,336 B+0,131 C+0,144 D+0,156 E
$$

\section{CONCLUSIONS}

The regression results reveal that decisions on municipal bond investment have positive relationship with the factors, and their effects are arranged in order of reducing importance: Factor group of laws and policies (group A); factor group of municipal bonds and issuers (group B); impacts of relevant markets (group E); economic factors (group D); and factor group of infrastructure development projects and socioeconomic factors (group C).

Table 7: Importance Order of the Factors

\begin{tabular}{|c|c|c|}
\hline Independent Variable & Absolute Value & Percentage \\
\hline A & 0.744 & $49.2 \%$ \\
\hline B & 0.336 & $22.2 \%$ \\
\hline $\mathrm{E}$ & 0.156 & $10.3 \%$ \\
\hline $\mathrm{D}$ & 0.144 & $9.5 \%$ \\
\hline $\mathrm{C}$ & 0.131 & $8.7 \%$ \\
\hline Total & 1.510 & $100 \%$ \\
\hline
\end{tabular}

Thus, to attract more investors to the municipal bond market to effectively facilitate its development and mobilize financial resources for HCMC infrastructure projects, the most urgent task is to improve laws and policies and create safe legal corridor for entities involved in the market. Next, there should be policies to encourage more commodities for the bond market and enhance of issuers' capability and creditworthiness. Furthermore, the development of relevant markets, steady economic growth and other factors related to the development of infrastructure or socioeconomic factors could foster the development of this market.

\section{POLICY RECOMMENDATIONS}

In order to maximize the mobilization of financial resources through HCM municipal bonds for infrastructure development, some policy recommendations are to be offered, 
focusing on two most influential groups: (1) Factor group of laws and policies; and (2) Factor group of municipal bonds and issuers.

\section{a. Factor Group of Laws and Policies:}

First, legal provisions should be completed specifically for municipal bond market. This is to promote the market development but still ensure the managerial role of the government and the rights of the participants for the sake of a legal environment in accordance with requirements from the market. The development of legal framework should well adapt to the following principles:

- It ensures an efficient operation of medium- and long-term capital market and centralized and unified management for issuers' and investors' interest, thereby making municipal bonds more attractive to investors.

- It should develop the municipal bond market according to national economic development goals in different phases and complying with all policies and guidelines put forward by the government.

Second, a specific decree on issuance regulations should be issued to guide the listing and transaction of the bonds on the stock market.

Third, legal documents on local debt management should be compliant with public debt management and national budget laws.

- At present, the Public Debt Law, due to a lack of its complete model in a national scale, have yet to specify the debt threshold but only establish a coefficient system to compare and evaluate the volatility of the national debt during the process of securing and employing loans. Moreover, it only stipulates that lawful sources of finance could be used to cover deficit but fails to introduce schemes of repaying public debts and specify what sources of finance are lawful.

- Establishment of a debt threshold could help manage the public debt at provincial level, thereby ensuring healthy financial basis and rational structure of public debts for each stage of development. At present, the public debt owed by provincial governments is still low and comes from loans or financial support from central agencies. Securing loans by issuing local bonds requires a mechanism for controlling public debt at provincial level to ensure a balanced local budget repayment of public debts.

Fourth, official guidelines on bond and derivatives repo on municipal bond market should be issued to help boost transactions in this market. 


\section{b. Factor Group of Municipal Bonds and Issuers:}

First, commodities for municipal bond market should be diversified.

Bonds to be issued should offer various maturities, interest rates and term of repayment to meet different demands by investors and financial market.

Second, encouragement to investors in municipal bond market is another concern.

Attracting commercial banks, insurance funds as investors along with foreign investing institutions to the municipal bond market could be done by building transparent information system and publicizing issuance plans at the beginning or end of each year. The use of mobilized funds and process of disbursement should also be officially and publicly announced for trust creation among investors.

Third, the development of bond market could be based on linkages between primary market and secondary one. A standard interest rate curve used as a reference could be developed to facilitate issuance, transactions, and investment in the bond market.

Fourth, as for methods of payment, the issuers are responsible for organizing an agent network corresponding to issuing agents to ensure convenience in bond payments. The Department of Finance, when the maturity date approaches, should transfer funds to issuers or settlement agents who pay principal and interest to bondholders.

Since municipal bonds are listed and traded, bond interest and principal payments should be uniformly made through such agency as Depository Center, which reduces the cost born by both issuers and investors. Regarding the payment method, the center should transfer the payments to individual account at the request of the bondholders.

Fifth, developing prospectuses for the issuance plans.

A prospectus that serves as an invitation or offer based on which investors purchase bonds or stocks from issuers should include all information related to the issues; therefore, the information provided in the prospectus should be associated with the provisions of invitation or offer implementation. In particular, information about socioeconomic and/or financial situations in the past and forecasting future financial prospects, possible sources of budget income needed for annual repayments of bond should also be transparent, fully informed, and clear.

Sixth, credit rating of municipal bonds needs conducting.

Cooperating with and learning from international credit rating organizations to develop a mechanism for rating government and municipal bonds are very needed. For 
the time being when credit rating has yet to be applicable, there should be other available measures to determine bond creditworthiness, which, in fact, are considered as temporary ones and merely applied for general obligation.

In the long term, to expand this channel, the bond issuing process should be improved and carried out according to international practices, and issuers ought to be rated by credit rating organizations. The credit rating may help issuers to make the best use of their competitive advantages over their rivals in other provinces or cities to attract local and foreign investors, thereby ensuring successful issuance of bonds at low costs. The credit ratings would accordingly function as another important information channel that ensures objectivity, transparency and credibility of bond investment. This task is more urgent when more and more foreign investors are interested in Vietnamese market after its financial market is liberalized and internationalized.

Seventh, issuers need determine the target debt portfolio, long-term costs and expected risks; organize market for bond listing and transaction; and replace nonperiodic issuance with periodic one with relevant information widely publicized

\section{Notes:}

[1] Selected respondents are working in finance and bond trade sectors.

[2] According to an article on the Journal of Finance Research, the optimum number of samples and variables for the regression function is $\mathrm{n} \geq 30+\mathrm{p}$ if the respondents are enterprises and $\mathrm{n} \geq \mathrm{p} \times 10$ as for individual respondents ( $\mathrm{n}$ : the number of samples; $\mathrm{p}$ : number of independent variables, $\mathrm{p}<$ 20). Moreover, Hoàng Trọng \& Chu Nguyễn Mộng Ngọc in their Phân tích dĩ liệu nghiên cúu vói SPSS (2008, Vol 2, p. 31) suggest that the number of samples are at least four or five times as many as that of observed variables in factor analysis. In this research, 180 samples chosen as representatives of the population are considered adequate for the analysis, establishment and construction of regression function.

[3] Tanaka,Y. (2011)

[4] HFIC: HCMC Investment Fund for Urban Development is authorized by HCM People's Committee to perform all operations in municipal bond issuance as regulated.

[5] According to Clause 3, Article 2, Chapter 1 of Decree No. 01/2011/NĐ-CP dated Jan. 5, 2011.

[6] Pursuant to Decree No. 01/2011/NĐ-CP dated Jan. 5, 2011. 


\section{References}

Đinh Thế Hiển (2002), "Một số giải pháp trong việc sử dụng trái phiếu đô thị ở thành phố Hồ Chí Minh", paper presented at workshop "Trái phiếu đô thị ở Việt Nam: Triển vọng và phương thức phát hành".

Harwood, A. (2000), Building Local Bond Markets: An Asian Perspective, Word Bank Publications.

HCMC People's Committee (2012), "Quy hoạch tổng thể phát triển kinh tế - xã họi TP.HCM đến năm 2020, tầm nhì đến năm 2025 ”.

Leigland, J. (1997), “Accelerating Municipal Bond Market Development in Emerging Economies: An Assessment of Strategies and Progress”, Public Budgeting \& Finance, Vol.17(2), pp.57-80.

Nguyễn Đình Tài \& Lê Thanh Tú (2010), "Nâng cao hiệu quả đầu tư công ở VN", Tài chính (April 2010), pp.21-24.

Nguyễn Ngọc Thanh \& Trần Mạnh Kiên (2002), "Một số chính sách thúc đẩy thị trường trái phiếu đô thị ở Việt Nam”, paper presented at workshop "Trái phiếu đô thị ở Việt Nam: Triển vọng và phương thức phát hành".

Peterson, G. (2000), Building Local Credit Systems, The World Bank.

Peterson, G. (2002), Bank or Bond: Building a Municipal Credit Market, The Urban Institute, Washington D.C.

Phạm Phan Dũng (2002), “Triển vọng phát triển trái phiếu đô thị ở Việt Nam”, paper presented at workshop "Trái phiếu đô thị ở Việt Nam: Triển vọng và phương thức phát hành".

Porter, M. (1998), Competitive Strategy - Techniques for Analyzing Industries and Competitors, The Free Press, New York, USA.

Trần Đắc Sinh (2002), Định mức tín nhiệm tại Việt Nam, Thành phố Hồ Chí Minh Publisher.

Trần Đắc Sinh (2004), Huy động vốn đầu tư cơ sở hạ tầng qua thị trường chứng khoán. Thành phố Hồ Chí Minh Publisher.

Steiss, A.W. (1975), Local Government Finance: Capital Facilities Planning and Debt Administration, Lexington Books.

Tanaka,Y. (2011), Local Bonds in Japan, Institute for Comparative Studies in Local Governance (COSLOG), Kagawa University. 